\title{
PENGARUH GREEN BRAND POSITIONING DAN GREEN BRAND KNOWLEDGE TERHADAP GREEN PURCHASE INTENTION MELALUI SIKAP PADA GREEN BRAND SEBAGAI VARIABEL MEDIASI
}

\author{
Linda Wahyuningtias ${ }^{1}$, Yessy Artanti ${ }^{2}$ \\ ${ }^{1}$ Jurusan Manajemen, Universitas Negeri Surabaya \\ Email: lindawahyuningtias16080574058@mhs.unesa.ac.id \\ ${ }^{2}$ Jurusan Manajemen, Universitas Negeri Surabaya \\ Email: yessyartanti@unesa.ac.id
}

Masuk : 16-06-2020, revisi: 12-07-2020, diterima untuk diterbitkan : 12-07-2020

\begin{abstract}
ABSTRAK
Meningkatnya kepedulian konsumen akan isu lingkungan dapat memengaruhi perilaku pembelian. Pemahaman dampak konsumsi terhadap lingkungan dapat mendorong konsumen dalam niat pembelian produk ramah lingkungan. Pada dasarnya setiap konsumen selalu menginginkan produk yang sehat, aman digunakan dan memiliki dampak pencemaran sekecil mungkin bagi lingkungannya. Niat pembelian produk ramah lingkungan atau dapat disebut green purchase intention dipengaruhi oleh beberapa faktor diantaranya adalah green brand positioning, green brand knowledge dan sikap pada green brand. Penelitian ini bertujuan untuk menganalisis dan membahas pengaruh green brand positioning dan green brand knowledge terhadap green purchase intention melalui sikap pada green brand sebagai variabel mediasi pada konsumen Aqua. Penelitian ini menggunakan nonprobability sampling dengan mengandalkan judgment dari peneliti untuk membidik responden. Responden adalah konsumen Aqua sekaligus green consumer yang mengetahui program Aqua Life dengan rentang umur 18 - 65 tahun sebanyak 200 reponden. Teknik analisis data menggunakan analisis jalur (path analysis). Hasil dari penelitian ini menunjukkan bahwa green brand positioning berpengaruh signifikan terhadap green purchase intention dan sikap pada green brand. Sedangkan green brand knowledge tidak berpengaruh signifikan terhadap green purchase intention namun berpengaruh signifikan terhadap sikap pada green brand. Untuk variabel sikap pada green brand dinyatakan memediasi secara sempurna green brand positioning dan green brand knowledge terhadap green purchase intention.
\end{abstract}

Kata Kunci: Green brand positioning, green brand knowledge, sikap pada green brand, green purchase intention

\begin{abstract}
Increased consumer awareness of environmental issues can influence purchasing behavior. Understanding the impact of consumption on the environment can encourage consumers in green product intention. Basically every consumer always wants a product that is healthy, safe to use and has the least possible pollution impact on the environment. The purchase intention environmentally friendly products or can be called green purchase intention is influenced by several factors among them are green brand positioning, green brand knowledge, and attitudes towards green brands. This study aims to analyze the effect of green brand positioning and green brand knowledge on green purchase intention through attitude towards green brand as a mediating variable for Aqua consumers. This research uses non probability sampling and judgmental sampling methode to target respondents. Respondents were Aqua consumers as well as green consumers who know the Aqua Life program with an age range of 18-65 years as many as 200 respondents. Data analysis techniques using path analysis. The results of this study examined that green brand positioning had significant effect on green purchase intention and attitude toward green brand while green brand knowledge had no significant effect on green purchase intention but had significant effect on attitudes toward green brands. The attitude toward green brand stated to perfectly mediate green brand positioning and green brand knowledge on green purchase intention.
\end{abstract}

Keywords: Green brand positioning, green brand knowledge, attitude toward green brand, green purchase intention

\section{PENDAHULUAN}

\section{Latar Belakang}

Pada era ini dampak buruk yang sangat dirasakan akibat kemajuan peradaban adalah kerusakan lingkungan akibat sampah plastik. Menurut penelitian Consumer News and Business Channel (CNBC Indonesia) tahun 2019, Indonesia menempati posisi kedua sebagai penyumbang sampah 
plastik terbanyak di dunia sebesar 1,29 ton per tahun. Sumber terbesar melimpahnya sampah plastik berasal dari industri makanan dan minuman yang mayoritas menggunakan plastik sekali pakai sebagai kemasan. Zat yang terkandung dalam plastik sangat berbahaya apabila masuk ke tubuh manusia. Masalah inilah yang mendorong kepedulian terhadap lingkungan dan memengaruhi pola konsumsinya. Seorang green consumer cenderung lebih memiliki niat beli terhadap produk ramah lingkungan atau dapat disebut green purchase intention. Suki (2016) menerangkan green purchase intention merupakan niat pembelian terhadap produk yang tidak membahayakan bagi lingkungan serta masyarakat luas. Ketika konsumen memiliki komitmen yang tinggi dalam menjaga lingkungan mereka akan lebih senang menggunakan produk ramah lingkungan.

Sebelum memiliki niat, konsumen akan memunculkan sikap sebagai preferensi terhadap merek. Huang, Yang \& Wang (2014) memaparkan sikap pada green brand sebagai refleksi dari preferensi konsumen dan evaluasi keseluruhan terhadap merek ramah lingkungan. Konsumen yang memiliki sikap positif terhadap green brand akan mendorong green purchase intention. Nilasari \& Kusumadewi (2016) beranggapan bahwa konsumen yang sangat peduli terhadap lingkungan akan memilih produk yang ramah lingkungan walaupun harganya relatif mahal. Namun, Gupta \& Ogden (2009) menyatakan pembelian produk ramah lingkungan belum tentu maksimal walaupun kepedulian lingkungan tinggi. Hal ini karena tidak diimbangi dengan daya beli yang cukup dan menganggap bahwa utilitas produk yang diberikan tidak sebanding dengan biaya yang dikeluarkan. Konsumen akan lebih memilih produk ramah lingkungan apabila tidak mengeluarkan biaya tambahan (Darnall, Pointing \& Vazquez, 2012). Hasil survei dari The Accenture Global Auto Consumer Survey of March 2010 yang dijelaskan oleh Drozdenko, Jensen \& Coelho (2011) juga menerangkan bahwa kesediaan konsumen untuk membayar lebih atas produk ramah lingkungan menurun, meskipun kekhawatiran konsumen akan isu - isu lingkungan meningkat. Kekhawtiran konsumen juga bertambah karena maraknya isu produk ramah lingkungan palsu (greenwashing) sehingga menurunnya kepercayaan.

Untuk menghilangkan efek negatif dari greenwashing perusahaan perlu berhubungan dan berkomunikasi dengan konsumen melalui green brand positioning yang jelas (Huang, Yang \& Wang, 2014). Huang, Yang \& Wang (2014) mengungkapkan green brand positioning merupakan atribut merek dan nilai tentang ramah lingkungan suatu perusahaan yang gencar dikampanyekan kepada konsumen. Semakin perusahaan gencar mengkomunikasikan green brand positioning semakin tinggi pula sikap positif konsumen dan hal ini sangat mendorong konsumen untuk memiliki niat pembelian produk ramah lingkungan. Selain green brand positioning konsumen juga harus memiliki green brand knowledge sebagai pertimbangan dalam green purchase intention. Green brand knowledge memberikan informasi tentang atribut merek yang unik dan manfaatnya terhadap lingkungan serta konsumen (Suki, 2016). Perusahaan harus mampu meyakinkan konsumen tentang bahayanya menggunakan produk berbahan kimia dan betapa baiknya jika menggunakan produk yang sehat dan ramah lingkungan sehingga konsumen memahami apa yang ditawarkan oleh perusahaan (Himawan, 2019). Informasi yang didapat kemudian akan membentuk sikap konsumen terhadap merek ramah lingkungan.

Berdasarkan penjelasan di atas penelitian ini bertujuan untuk menganalisis pengaruh green brand positioning dan green brand knowledge terhadap green purchase intention melalui sikap pada green brand sebagai variabel mediasi. Objek penelitian ini adalah Air mineral dalam kemasan dengan merek Aqua yang telah meluncurkan lini produk baru yaitu Aqua Life 100\% recycle yang terbuat dari $100 \%$ plastik daur ulang dan $100 \%$ dapat didaur ulang kembali. 


\section{Rumusan Masalah}

Berdasarkan latar belakang diatas, masalah yang akan dikaji adalah :

1. Apakah green brand positioning berpengaruh signifikan terhadap green purchase intention Aqua Life $100 \%$ Recycle?

2. Apakah green brand knowledge berpengaruh signifikan terhadap green purchase intention Aqua Life $100 \%$ Recycle?

3. Apakah green brand positioning berpengaruh signifikan terhadap sikap pada green brand Aqua Life $100 \%$ Recycle?

4. Apakah green brand knowledge berpengaruh signifikan terhadap sikap pada green brand Aqua Life $100 \%$ Recycle?

5. Apakah sikap pada green brand berpengaruh signifikan terhadap green purchase intention Aqua Life $100 \%$ Recycle?

\section{Hipotesis}

Berdasarkan rumusan masalah diatas berikut hipotesis penelitian yang telah ditetapkan:

H1 : Green brand positioning berpengaruh signifikan terhadap green purchase intention Aqua Life $100 \%$ Recycle

H2 : Green brand knowledge berpengaruh signifikan terhadap green purchase intention Aqua Life $100 \%$ Recycle

H3 : Green brand positioning berpengaruh signifikan terhadap sikap pada green brand Aqua Life $100 \%$ Recycle

H4 : Green brand knowledge berpengaruh signifikan terhadap sikap pada green brand Aqua Life $100 \%$ Recycle

H5 : Sikap pada green brand berpengaruh signifikan terhadap green purchase intention Aqua Life $100 \%$ Recycle

Berdasarkan hipotesis yang telah ditentukan, adapun model penelitian dapat dilihat pada gambar 1.

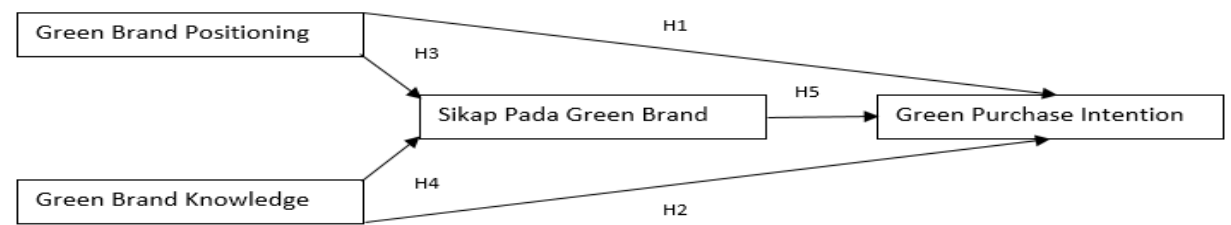

\section{Gambar 1. Model Penelitian}

\section{METODE PENELITIAN}

Responden penelitian ini yaitu konsumen peduli lingkungan yang sudah mengenal program Aqua Life dengan rentang umur 18-65 tahun. Teknik sampling menggunakan non probability dengan judgmental. Responden yang dibutuhkan sebesar 30 responden untuk uji validitas dan reliabilitas serta 200 responden untuk pengujian hipotesis. Pengukuran jawaban responden menggunakan skala likert dengan rentang 1 (sangat tidak setuju) sampai 5 (sangat setuju). Pengumpulan data dilakukan dengan menyebarkan angket online pada komunitas peduli lingkungan di sosial media facebook, twitter dan instagram. Peneliti juga menyebarkan angket melalui direct message pada green consumer yang tidak tergabung dalam komunitas. Teknik analisis data menggunakan analisis jalur (path analysis). Penelitian ini menggunakan software pengolahan data SPSS versi 22 dan AMOS versi 24. Berikut adalah pengukuran variabel yang dapat dilihat pada tabel 1 : 
Tabel 1. Pengukuran Variabel Penelitian

\begin{tabular}{|c|c|c|}
\hline No & Variabel & Item \\
\hline 1 & \multirow{7}{*}{$\begin{array}{l}\text { Green Brand } \\
\text { Positioning }\end{array}$} & Merek mewakili kenyamanan \\
\hline 2 & & Merek berkualitas tinggi \\
\hline 3 & & Merek harus aman \\
\hline 4 & & Merek haruslah professional \\
\hline 5 & & Merek yang bagus menggunakan teknologi tinggi \\
\hline 6 & & Merek ramah lingkungan rendah polusi \\
\hline 7 & & Merek ramah lingkungan harus memiliki sifat berkelanjutan \\
\hline 8 & \multirow{4}{*}{$\begin{array}{l}\text { Huang, Yang \& Wang } \\
\text { (2014) }\end{array}$} & Merek ramah lingkungan sangat kreatif \\
\hline 9 & & Merek ramah lingkungan berorientasi terhadap keluarga untuk mendukung pola hidup sehat \\
\hline 10 & & Merek ramah lingkungan sudah dikenal dengan baik \\
\hline 11 & & Merek ramah lingkungan adalah kehormatan \\
\hline 12 & \multirow{3}{*}{$\begin{array}{l}\text { Green Brand } \\
\text { Knowledge }\end{array}$} & Produk ramah lingkungan bisa menjadi investasi menguntungkan dalam jangka panjang \\
\hline 13 & & Saya mengetahui bahwa merek merilis produk ramah lingkungan \\
\hline \multirow{2}{*}{$\begin{array}{ll}14 \\
15\end{array}$} & & Merek adalah yang pertama saya ingat ketika memikirkan tentang produk ramah lingkungan \\
\hline & $\begin{array}{l}\text { Suki (2016) dan Huang, } \\
\text { Yang \& Wang (2014) }\end{array}$ & Produk ramah lingkungan memiliki reputasi yang bagus \\
\hline 16 & \multirow{4}{*}{$\begin{array}{c}\text { Sikap Pada Green } \\
\text { Brand }\end{array}$} & Saya merasa klaim ramah lingkungan dapat dipercaya \\
\hline 17 & & Saya pikir merek dapat mewakili status sosial ekonomi saya \\
\hline 18 & & Saya pikir fungsi merek dapat memenuhi kebutuhan saya \\
\hline 19 & & Saya pikir harga produk ramah lingkungan memuaskan bagi saya \\
\hline 20 & \multirow{5}{*}{$\begin{array}{l}\text { Suki (2016) dan Huang, } \\
\text { Yang \& Wang (2014) }\end{array}$} & Saya pikir produk ramah lingkungan lebih handal dari produk biasa \\
\hline 21 & & Kepedulian produk ramah lingkungan terhadap lingkungan memenuhi harapan \\
\hline 22 & & Produk ramah lingkungan menepati janji dan tanggung jawab terhadap lingkungan \\
\hline 23 & & Saya menyukai pandangan tentang produk ramah lingkungan \\
\hline 24 & & Fungsi ramah lingkungan dapat dipercaya \\
\hline 25 & \multirow{3}{*}{$\begin{array}{c}\text { Green Purchase } \\
\text { Intention } \\
\text { Suki (2016) dan Huang, } \\
\text { Yang \& Wang (2014) }\end{array}$} & $\begin{array}{l}\text { Saya berniat membeli produk ramah lingkungan karena kepedulian saya terhadap } \\
\text { lingkungan. }\end{array}$ \\
\hline \multirow[t]{2}{*}{26} & & $\begin{array}{l}\text { Saya berharap bisa membeli produk ramah lingkungan di masa depan karena bermanfaat } \\
\text { bagi lingkungan. }\end{array}$ \\
\hline & & Kemungkinan pembelian saya terhadap produk ramah lingkungan tinggi \\
\hline
\end{tabular}

\section{HASIL DAN PEMBAHASAN}

\section{Hasil}

Berikut adalah item pengukuran yang sudah memenuhi uji validitas dan reliabilitas.

Tabel 2. Hasil Uji Validitas dan Reliabilitas

Sumber : Data diolah oleh peneliti

\begin{tabular}{|c|c|c|c|c|}
\hline No & Variabel & Item & $\begin{array}{l}\text { Correlated } \\
\text { Item-Total }\end{array}$ & $\begin{array}{l}\text { Croncbach } \\
\text { Alpha }\end{array}$ \\
\hline 1 & \multirow[t]{4}{*}{$\begin{array}{l}\text { Green Brand } \\
\text { Positioning }\end{array}$} & $\begin{array}{l}\text { Aqua Life memberikan kenyamanan karena tidak berbahaya } \\
\text { bagi lingkungan }\end{array}$ & 0,860 & 0,960 \\
\hline 2 & & Aqua Life berkualitas tinggi karena produk ramah lingkungan & 0,852 & \\
\hline 3 & & Aqua Life sangat aman bagi lingkungan & 0,788 & \\
\hline 4 & & Aqua Life sangatlah profesional dalam menjaga lingkungan & 0,877 & \\
\hline 5 & \multirow{7}{*}{$\begin{array}{l}\text { Huang, Yang \& } \\
\text { Wang (2014) }\end{array}$} & $\begin{array}{l}\text { Aqua Life menggunakan teknologi tinggi dalam pengolahan } \\
\text { kemasan ramah lingkungan }\end{array}$ & 0,822 & \\
\hline 6 & & Aqua Life rendah polusi karena meminimalisir sampah plastik & 0,790 & \\
\hline 7 & & $\begin{array}{l}\text { Aqua Life harus memiliki sifat berkelanjutan karena kemasan } \\
\text { dapat didaur ulang secara berkelanjutan }\end{array}$ & 0,820 & \\
\hline 8 & & $\begin{array}{l}\text { Aqua Life sangat kreatif karena sudah menggunakan kemasan } \\
\text { daur ulang dan dapat didaur ulang }\end{array}$ & 0,845 & \\
\hline 9 & & $\begin{array}{l}\text { Aqua Life berorientasi terhadap keluarga untuk mendukung } \\
\text { pola hidup sehat }\end{array}$ & 0,843 & \\
\hline 10 & & Aqua Life sudah dikenal dengan baik & 0,668 & \\
\hline 11 & & $\begin{array}{l}\text { Saya akan merasa bangga jika enggunakan Aqua Life karena } \\
\text { ramah lingkungan }\end{array}$ & 0,832 & \\
\hline 12 & \multirow[t]{2}{*}{$\begin{array}{l}\text { Green Brand } \\
\text { Knowledge }\end{array}$} & $\begin{array}{l}\text { Aqua Life bisa menjadi investasi menguntungkan dalam jangka } \\
\text { panjang karena produk tidak berbahaya bagi lingkungan }\end{array}$ & 0,695 & 0,899 \\
\hline 13 & & Saya mengetahui bahwa Aqua merilis Aqua Life sebagai & 0,794 & \\
\hline
\end{tabular}




\begin{tabular}{|c|c|c|c|c|}
\hline & \multirow{3}{*}{$\begin{array}{l}\text { Suki (2016) dan } \\
\text { Huang, Yang \& } \\
\text { Wang (2014) }\end{array}$} & \multicolumn{2}{|l|}{ produk ramah lingkungan } & \\
\hline 14 & & $\begin{array}{l}\text { Aqua Life adalah yang pertama saya ingat ketika memikirkan } \\
\text { tentang produk ramah lingkungan }\end{array}$ & 0,768 & \\
\hline 15 & & $\begin{array}{l}\text { Aqua Life memiliki reputasi yang bagus sebagai produk ramah } \\
\text { lingkungan }\end{array}$ & 0,903 & \\
\hline 16 & $\begin{array}{l}\text { Sikap Pada Green } \\
\text { Brand }\end{array}$ & $\begin{array}{l}\text { Saya merasa klaim ramah lingkungan Aqua Life dapat } \\
\text { dipercaya }\end{array}$ & 0,902 & 0,971 \\
\hline 17 & \multirow{8}{*}{$\begin{array}{c}\text { Suki (2016) dan } \\
\text { Huang, Yang \& } \\
\text { Wang (2014) }\end{array}$} & $\begin{array}{l}\text { Saya pikir Aqua Life dapat mewakili status sosial ekonomi saya } \\
\text { karena lebih memilih produk ramah lingkungan yang mungkin } \\
\text { harganya berbeda dengan produk sejenis lainnya }\end{array}$ & 0,784 & \\
\hline 18 & & $\begin{array}{l}\text { Saya pikir fungsi Aqua Life dapat memenuhi kebutuhan saya } \\
\text { akan produk yang tidak berbahaya }\end{array}$ & 0,868 & \\
\hline 19 & & $\begin{array}{l}\text { Saya pikir harga Aqua Life memuaskan bagi saya karena } \\
\text { sepadan dengan manfaat yang diberikan }\end{array}$ & 0,916 & \\
\hline 20 & & $\begin{array}{l}\text { Saya pikir Aqua Life lebih handal dari produk biasa karena } \\
\text { memberikan manfaat lebih bagi lingkungan }\end{array}$ & 0,837 & \\
\hline 21 & & $\begin{array}{l}\text { Kepedulian Aqua Life terhadap lingkungan memenuhi harapan } \\
\text { saya untuk mengurangi populasi sampah plastik }\end{array}$ & 0,885 & \\
\hline 22 & & $\begin{array}{l}\text { Aqua Life menepati janji dan tanggung jawab terhadap } \\
\text { lingkungan dengan eminimalisir sampah plastik }\end{array}$ & 0,8921 & \\
\hline 23 & & $\begin{array}{l}\text { Saya menyukai pandangan tentang Aqua Life yang merupakan } \\
\text { prodk ramah lingkungan }\end{array}$ & 0,901 & \\
\hline 24 & & Fungsi ramah lingkungan Aqua Life dapat dipercaya & 0,900 & \\
\hline 25 & \multirow{3}{*}{$\begin{array}{l}\text { Green Purchase } \\
\text { Intention } \\
\text { Suki (2016) dan } \\
\text { Huang, Yang \& } \\
\text { Wang (2014) }\end{array}$} & $\begin{array}{l}\text { Saya berniat membeli Aqua Life karena kepedulian saya } \\
\text { terhadap lingkungan. }\end{array}$ & 0,746 & \multirow[t]{3}{*}{0,892} \\
\hline 26 & & $\begin{array}{l}\text { Saya berharapbisa membeli Aqua Life di masa depan karena } \\
\text { bermanfaat bagi lingkungan. }\end{array}$ & 0,855 & \\
\hline 27 & & Kemungkinan pembelian saya terhadap Aqua Life tinggi. & 0,764 & \\
\hline
\end{tabular}

Untuk mengukur kelayakan dapat dilihat dari nilai correlated item-total dan cronbach alpha dari masing masing pernyataan yang dibuat. Pada penelitian ini, $r$ tabel yang digunakan adalah 0,3610 dengan asumsi tingkat kesalahan sebesar 5\%. Menurut Ghozali (2016:52-53) jika r hitung $>\mathrm{r}$ tabel dan bernilai positif maka dapat dijelaskan bahwa pernyataan yang digunakan untuk meneliti dapat dikatakan valid. Berdasarkan hasil pengujian item pengukuran dinyatakan valid sebab $\mathrm{r}$ hitung $>\mathrm{r}$ tabel $(0,3610)$. Pengujian reliabilitas dalam penelitian ini dilakukan kepada 30 orang yang sama dengan uji validitas. Hasil perhitungan dari setiap variabel dikatakan reliabel jika nilai Cronbach's Alpha > 0,70 (Ghozali, 2016:47-48). Item pengukuran juga dinyatakan reliabel karena menghasilkan nilai Cronbach's Alpha Based on Standardized Items > 0,70. Maka, item dapat digunakan sebagai alat ukur pengaruh green brand positioning, green brand knowledge dan sikap pada green brand terhadap green purchase intention.

Selanjutnya dilakukan uji analisis jalur dengan software AMOS versi 24. Menurut Setiawan \& Ritonga (2011:71) ada beberapa tahapan uji analisis jalur. Pada uji normalitas dan uji outlier data dapat dilanjutkan ke tahap selanjutnya hanya apabila data berdistribusi normal dan tidak terdeteksi sebagai outlier. Berdasarkan hasil dari analisi jalur yang telah dilakukan menunjukkan bahwa data berdistribusi normal karena nilai variabel dan multivariate berada pada rentang 2,58....2,58. Pada uji linearitas hubungan dari semua variabel menunjukkan probabilitas $0,000<$ 0,05 yang berarti semua variabel dapat dikatakan linear Hasil mahalanobis distance menunjukkan tidak ada data outlier yang terdeteksi. Hal ini karena nilai mahalanobis $d$-squared tidak ada yang lebih besar dari nilai critical value of chi square 0,001 dengan $\mathrm{dF}$ sebesar 5 yaitu $\mathrm{X}^{2}=18,4668$. Pada uji multikolinearitas nilai determinant of sample covariance matrix jauh dari 0 , yaitu sebesar 1857,933 . Maka, dapat disimpulkan bahwa tidak terdapat multikolinearitas ataupun singularitas pada penelitian ini.

Hasil uji kelayakan model menyebutkan bahwa variabel sikap pada green brand yang disebabkan adanya kontribusi variabel green brand positioning dan green brand knowledge 
adalah sebesar 69,2\%. Sedangkan nilai koefisien determinasi variabel green brand positioning, green brand knowledge dan sikap pada green brand terhadap green purchase intention sebesar $43,1 \%$. Maka sesuai rumus $\mathrm{R}^{2}$ model $=1-\left(1-\mathrm{R}^{2} 1\right)\left(1-\mathrm{R}^{2} 2\right)$ perhitungan ketepatan model menghasilkan nilai sebesar $82,5 \%$. Hasil tersebut dapat diartikan bahwa hubungan struktural dari variabel yang diteliti sebesar $82,5 \%$ sisanya $17,5 \%$ disebabkan oleh variabel lain yang tidak terlibat dalam model. Selanjutnya untuk pengujian hipotesis dapat dilakukan dengan membandingkan CR hitung dengan CR standard pada $\alpha$ sebesar 0,05 yaitu 2,00. Apabila suatu hipotesis memiliki $C R$ hitung $\geq 2,00$ maka suatu hubungan variabel signifikan dan terdapat pengaruh variabel dependen terhadap variabel independen lalu dengan membandingkan hasil tingkat signifikansi dengan tingkat signifikansi yang telah ditentukan. Apabila hasil tingkat signifikansi $(\mathrm{P}) \leq 0,05$, maka terdapat pengaruh variabel $\mathrm{x}$ terhadap variabel $\mathrm{y}$.

Tabel 3. Hasil Uji Hipotesis

Sumber : Data primer diolah oleh peneliti

\begin{tabular}{lcc}
\hline & C.R & P \\
\hline Green Brand Positioning $\rightarrow$ Green Purchase Intention & 2,444 & 0,015 \\
\hline Green Brand Knowledge $\rightarrow$ Green Purchase Intention & 0,705 & 0,481 \\
\hline Green Brand Positioning $\rightarrow$ Sikap Pada Green Brand & 9,512 & 0,000 \\
\hline Green Brand Knowledge $\rightarrow$ Sikap Pada Green Brand & 5,817 & 0,000 \\
\hline Sikap Pada Green Brand $\rightarrow$ Green Purchase Intention & 4,217 & 0,000 \\
\hline
\end{tabular}

Pada hubungan antara green brand positioning terhadap green purchase intention nilai CR hitung sebesar 2,444 $>2,00$ dan nilai signifikansi sebesar 0,015 $<0,05$ maka green brand positioning berpengaruh signifikan terhadap green purchase intention. Pada hubungan antara green brand knowledge terhadap green purchase intention nilai CR hitung sebesar 0,705 <2,00 dan nilai nilai signifikansi sebesar 0,481>0,05 maka, green brand knowledge tidak berpengaruh signifikan terhadap green purchase intention. Pada hubungan antara green brand positioning terhadap sikap pada green brand nilai CR hitung sebesar 9,512> 2,00 dan nilai signifikansi sebesar $0,000<0,05$ maka ada pengaruh signifikan green brand positioning terhadap sikap pada green brand. Pada hubungan antar green brand knowledge terhadap sikap pada green brand nilai CR hitung sebesar 5,817 > 2,00 dan nilai signifikansi sebesar $0,000<$ 0,05 maka adanya pengaruh signifikan green brand knowledge terhadap sikap pada green brand. Hubungan sikap pada green brand terhadap green purchase intention menghasilkan nilai CR hitung sebesar 4,217 > 2,00 dan nilai signifikansi sebesar 0,000 $<0,05$ maka terdapat pengaruh signifikan sikap pada green brand terhadap green purchase intention.

Kemudian hasil uji mediasi menunjukkan bahwa pada jalur green brand positioning sikap pada green brand memediasi secara sempurna hubungan green brand positioning terhadap green purchase intention, dapat dilihat dari nilai koefisien B yang menurun disertai 0 yaitu sebesar 0,082 ketika variabel sikap pada green brand ditambahkan. Begitupun pada jalur green brand knowledge sikap pada green brand memediasi secara sempurna hubungan green brand knowledge terhadap green purchase intention, dapat dilhat dari nilai koefisien B yang menurun disertai 0 yaitu sebesar 0,097 ketika variabel sikap pada green brand ditambahkan. Hasil uji sobel dapat dilihat pada tabel 4 .

Tabel 4. Hasil Uji Sobel

Sumber : Data diolah oleh peneliti

\begin{tabular}{lccc}
\hline & Test Statistict & Std. Error & P-Value \\
\hline Green Brand Positioning & 4,802 & 0,024 & 0,002 \\
\hline Green Brand Knowledge & 6,076 & 0,045 & 0 \\
\hline
\end{tabular}


Berdasarkan nilai hasil uji sobel, sikap pada green brand memediasi hubungan green brand positioning terhadap green purchase intention karena menghasilkan nilai uji sobel 4,802 > 1,96. Begitupun green brand knowledge yang menghasilkan nilai sebesar 6,076 > 1,96 sehingga dapat dimaknai sikap pada green brand memediasi green brand knowledge terhadap green purchase intention.

\section{Pembahasan}

Berdasarkan uji yang telah dilakukan, peneliti mendapatkan hasil bahwa green brand positioning berpengaruh signifikan terhadap green purchase intention. Apabila Aqua Life menekankan green brand positioning konsumen Aqua akan semakin akan semakin tertanam di benak konsumen sehingga dapat mendorong green purchase intention. Namun, banyaknya isu-isu pemalsuan produk ramah lingkungan yang beredar dapat memperburuk citra produk ramah lingkungan yang sebenarnya. Konsumen yang tidak mempercayai kebenaran akan green brand positioning Aqua Life akan menunjukkan sikap negatif terhadap merek. Konsumen akan menganggap Aqua Life 100\% recycle yang dijual oleh perusahaan tidak benar-benar ramah lingkungan. Maka, penting bagi Aqua dalam mengampanyekan green brand positioning Aqua Life 100\% recycle untuk meyakinkan konsumen bahwa Aqua Life 100\% recycle benar-benar tidak berbahaya bagi lingkungan. Aqua Life dapat membuat program-program yang dapat mengampanyekan green brand positioning Aqua Life 100\%recycle. Hasil dari penelitian ini mendukung pernyataan (Suki, 2016; Himawan, 2019; Hanjani \& Widodo, 2019 dan Tristiani, Amanda \& Dharmoputro, 2019) bahwa green brand positioning berpengaruh signifikan terhadap green purchase intention.

Dari hasil uji yang didapatkan peneliti mengetahui bahwa green brand knowledge tidak berpengaruh signifikan terhadap green purchase intention. Seorang konsumen harus memiliki pengetahuan terhadap merek hijau sebagai pertimbangan untuk mengonsumsi produk. Konsumen cerdas perlu mengetahui produk yang akan dikonsumsi dan memilih secara tepat merek yang akan dipilih. Namun, pada kenyataannya walaupun konsumen memiliki green brand knowledge yang tinggi tidak ada pengaruhnya terhadap green purchase intention. Ini dapat disebabkan oleh banyak faktor seperti daya beli, kemudahan, ketersediaan produk dan kepercayaan. Umumnya, produk ramah lingkungan memiliki harga yang cenderung lebih mahal dari produk lainnya karena memiliki kualitas yang lebih unggul. Ini juga berlaku terhadap Aqua Life yang memiliki harga yang lebih mahal dengan kuantias lebih sedikit. Dalam hasil penelitian Febriani (2019) menyebtkan bahwa green product dan green price berpengaruh kuat dalam green purchase intention sehingga perusahaan perlu mengutamakan kualitas produk dan menekan harga untuk menarik green purchase intention konsumen. Sebaiknya, langkah ini juga dilakukan oleh Aqua Life 100\% recycle. Aqua Life 100\% recycle dibandrol dengan kisaran harga Rp. 8.000,00 /1,1 liter sedangkan Aqua konvensional memiliki harga sekitar Rp.6000,00/1,5 liter. Ini akan menjadi masalah bagi konsumen Aqua yang sensitif terhadap harga. Penelitian ini membantah hasil penelitian dari (Suki, 2016; Shidiq \& Widodo, 2018; Hanjani \& Widodo, 2019 dan Salimi, 2018).

Penelitian ini menyatakan green brand positioning berpengaruh signifikan terhadap sikap pada green brand. Pemasar harus gencar mengampanyekan green brand positioning Aqua Life 100\% recycle untuk meningkatkan kesadaran konsumen sehingga dapat memberikan sikap positif pada merek. Green brand positioning dikatakan berhasil apabila konsumen Aqua menyadari Aqua Life dan mempercayai bahwa Aqua Life 100\% recycle benar-benar ramah lingkungan. Jika konsumen Aqua sudah mempercayai dan meyakini Aqua Life 100\% recycle akan mudah bagi pemasar untuk menarik niat pembelian konsumen. Penelitian ini memperkuat penelitian (Suki, 
2016; Huang, Yang \& Wang, 2014) yang menyatakan green brand positioning berpengaruh signifikan terhadap sikap pada green brand. Namun menolak penelitian Aulina \& Yuliati (2017) yang menyatakan green brand positioning tidak berpengaruh signifikan terhadap sikap pada green brand.

Mengacu pada hasil penelitian yang telah dilakukan green brand knowledge terbukti berpengaruh signifikan terhadap sikap pada green brand. Konsumen Aqua akan mengevaluasi pengetahuan yang dimiliki dan informasi yang didapat untuk menilai Aqua Life $100 \%$ recycle. Konsumen yang memiliki pemahaman yang luas tentang green brand akan lebih memilih menggunakan produk tersebut karena kebutuhan konsumen atas kelayakan produk, keamanan produk dan kepedulian konsumen terhadap keberlanjutan lingkungan. Green brand knowledge konsumen dapat diketahui dari seberapa paham konsumen tentang merek ramah lingkungan, merek mana saja yang mempositioningkan diri sebagai merek ramah lingkungan, mengetahui kandungan suatu produk ramah lingkungan, memahami manfaat lebih produk ramah lingkungan dibanding produk konvesional. Hasil penelitian ini mendukung penelitian dari (Suki, 2016; Huang, Yang \& Wang, 2014 dan Aulina \& Yuliati, 2017) bahwa green brand knowledge terbukti berpengaruh signifikan terhadap sikap pada green brand.

Hasil menunjukkan bahwa sikap pada green brand berpengaruh signifikan terhadap green purchase intenton. Ketika konsumen merupakan green consumerism mereka akan memiliki sikap positif pada Aqua Life 100\% recycle dan kemudian memiliki niat atau memutuskan untuk membeli. Akan tetapi, apabila konsumen memiliki sikap negatif pada Aqua Life atau kurang mempercayai bahwa Aqua Life 100\% recycle benar - benar ramah lingkungan, konsumen akan lebih memilih Aqua konvensional yang sudah diyakini atau sering digunakan. Selain itu, konsumen juga dapat merasa Aqua Life 100\% recycle kurang memberikan manfaat dengan harga yang lebih mahal. Sikap konsumen pada green brand menunjukan langkah selanjutnya dari perilaku konsumsi. Maka, apabila sikap konsumen Aqua pada Aqua Life sangat positif akan memiliki peluang yang tinggi bagi konsumen Aqua dalam green purchase intention. Penelitian ini memperkuat penelitian dari (Huang, Yang \& Wang, 2014 dan Suki, 2016) yang menghasilkan bahwa sikap pada green brand memediasi secara signifikan green brand positioning dan green brand knowledge terhadap green purchase intention. Aulina \& Yuliati (2017) juga menyatakan sikap memediasi green brand knowledge terhadap green purchase intention. Namun, penelitian ini membantah hasil penelitian Aulina \& Yuliati (2017) yang menyatakan sikap tidak memediasi green brand positioning terhadap green purchase intention.

\section{KESIMPULAN DAN SARAN}

\section{Kesimpulan}

Berdasarkan hasil dan pembahasan sebelumnya, dapat ditarik kesimpulan bahwa :

a) Green brand positioning berpengaruh signifikan terhadap green purchase intention pada Aqua Life $100 \%$ Recycle

b) Green brand knowledge tidak berpengaruh signifikan terhadap green purchase intention pada Aqua Life 100\% Recycle

c) Green brand positioning berpengaruh signifikan terhadap sikap pada green brand pada Aqua Life $100 \%$ Recycle

d) Green brand knowledge berpengaruh signifikan terhadap sikap pada green brand pada Aqua Life $100 \%$ Recycle

e) Sikap pada green brand berpengaruh signifikan terhadap green purchase intention pada Aqua Life $100 \%$ Recycle 
f) Variabel sikap pada green brand terbukti memediasi sempurna hubungan green brand positioning dan green brand knowledge terhada green purchase intention.

\section{Saran}

Berdasarkan pembahasan dan kesimpulan, berikut adalah saran untuk penelitian yang akan datang sekaligus implikasi manajaerial dari penelitian ini:

a) Untuk penelitian di masa depan, diharapkan dapat menggunakan variabel bebas lainnya yang mampu mempengaruhi green purchase intention karena terdapat peluang 17,5\% yang dipengaruhi oleh variabel lain. Penyebaran angket juga dapat dilakukan juga secara offline karena masih terdapat peluang usia 30-65 tahun yang dapat menjadi responden namun kemungkinan terhalang karena tidak memiliki media sosial. Angket yang disebarkan pada komunitas dan non komunitas dapat dibedakan atau dapat menambahkan pertanyaan apakah responden tergabung dalam komunitas atau tidak. Hal ini berguna untuk mengetahui jumlah responden yang termasuk komunitas dan non komunitas.

b) Diharapkan hasil dari penelitian ini dapat membantu dalam kegiatan pemasaran Aqua $100 \%$ recycle. Pemasar diharapkan dapat menekankan green brand positioning karena terbukti secara segnifikan memengaruhi green purchase intention konsumen. Aqua dapat menekankan green brand positioning dengan membuat program-program promosi seperti event peduli lingkungan dengan promosi Aqua Life 100\% recycle, periklanan Aqua Life $100 \%$ recycle di berbagai media, Aqua juga bisa menggunakan jasa selebriti, para ahli dan orang biasa untuk membantu mengomunikasikan green brand positioning Aqua Life 100\% recycle. Selain itu dapat dilakukan demo uji coba kebenaran ramah lingkungan Aqua Life yang kemudian dipublikasikan. Pada penelitian ini green brand knowledge tidak berpengaruh signifikan terhadap green purchase intention kecuali di mediasi oleh sikap pada green brand. Maknanya, kurangnya pengetahuan tentang merek ramah lingkungan menghambat niat belinya. Sehingga Aqua dapat melakukan event edukasi dan sosialisasi tentang penggunaan ramah lingkungan. Event ini dapat dilakukan sekali waktu dengan CSR perusahaan. Jika konsumen memiliki pengetahuan yang baik tentang Aqua Life 100\% recycle akan menumbuhkan sikap positif terhadap merek dan itu baik untuk memunculkan niat.

\section{REFERENSI}

Adharsyah, T. (2019, July 21). Sebegini Parah Ternyata Masalah Sampah Plastik Di Indonesia. Retrieved From Cnbc Indonesia: Https://Www.Cnbcindonesia.Com/Lifestyle/20190721140139-33-86420/Sebegini-ParahTernyata-Masalah-Sampah-Plastik-Di-Indonesia

Aulina, L., \& Yuliati, E. (2017). The Effects Of Green Brand Positioning, Green Brand Knowledge, And Attitude Towards Green Brand On Green Products Purchase Intention. 36(Icbmr), 548-557.

Darnall, N., Pointing, C., \& Vazquez-Brust, D. (2009). Why Consumers Buy Green.

Drozdenko, R., Jensen, M., \& Coelho, D. (2011). Pricing Of Green Products: Premiums Paid, Consumer Characteristics And Incentives. International Journal Of Business, Marketing, And Decision Sciences, 4(1), 106. Retrieved From Http://Go.Galegroup.Com.Proxy.Lib.Umich.Edu/Ps/I.Do?P=Aone\&U=Lom_Umichanna\&

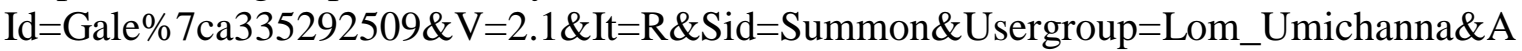
uthcount $=$

Febriani, S. (2019). Pengaruh Green Marketing Mix Terhadap Green Product Purchase Intention Pada Produk Innisfree Di Jakarta Dengan Consumer's Attitude Sebagai Variabel Mediasi. Jurnal Manajemen dan Kewirausahaan, 3(1), 49-60. Jakarta: Universitas Tarumanegara.

Ghozali, I. (2016). Aplikasi Analisis Multivariate dengan Program IBM SPSS 23 (Ke Delapan). 
Semarang: Badan Penerbit Universitas Diponegoro

Gupta, S., \& Ogden, D. T. (2009). To Buy Or Not To Buy? A Social Dilemma Perspective On Green Buying. Journal Of Consumer Marketing, 26(6), 378-393.

Hanjani, G. A., \& Widodo, A. (2019). Consumer Purchase Intention: The Effect Of Green Brand And Green Knowledge On Indonesian Nestle Company. Jurnal Sekretaris \& Administrasi Bisnis. Iii(1). 39-50.

Himawan, E. (2019). Pengaruh Green Brand Positioning, Green Brand Attitude, Green Brand Knowledge Terhadap Green Purchase Intention. Jurnal Manajemen Bisnis dan Kewirausahaan, 3(2), 110-115. Jakarta: Universitas Tarumanegara.

Huang, Y. C., Yang, M., \& Wang, Y. C. (2014). Effects Of Green Brand On Green Purchase Intention. Marketing Intelligence And Planning, 32(3), 250-268.

Nilasari, N. P. H., \& Kusumadewi, N. M. W. (2016). Peran Sikap Dalam Memediasi Pengaruh Kepedulian Lingkungan Terhadap Niat Beli Kosmetik Hijau Merek The Body Shop. Jurnal Manajemen Universitas Udayana. 5(2), 821-848.

Salimi, A. R. (2019). Effects Of Environmental Concerns And Green Knowledge On Green Product Consumptions With An Emphasis On Mediating Role Of Perceived Behavioral Control, Perceived Value, Attitude, And Subjective Norm. International Transaction Journal Of Engineering, Management, \& Applied Sciences \& Technology, 10(5), 651-661.

Setiawan, I. A., \& Ritonga, F. (2011). Analisis Jalur (Path Analysis) dengan Menggunakan Program AMOS. Tangerang: Graha Ilmu.

Shidiq, A. N. M \& Widodo, A. (2018). Green Product Purchase Intention: Impact Of Knowledge And Green Attitude Minat Pembelian Produk Ramah Lingkungan: Dampak Pengetahuan Dan Sikap Berwawasan Lingkungan. Ii(2), 60-73.

Suki, N. M. (2016). Green Product Purchase Intention: Impact Of Green Brands, Attitude, And Knowledge. British Food Journal, 118(12), 2893-2910.

Tristiani, R. I., Amanda, D., \& Dharmoputro, S., Toward, A., Brand, G., Brand, G., ... Purchase, G. (2019). Pengaruh Green Brand Positioning , Attitude Toward Green Brand Dan Green Brand Knowledge Terhadap Green Purchase Intention Pada Motor Gesits Di Kota Jakarta The Impact Of Green Brand Positioning, Attitude Toward Green Brand Knowledge On Green Purchase In. 6(1), 357-361. 